Am J Psychiatry Vol. 161(6):1125-1127 (2004)

ISSN: (print 0002-953X)(online 1535-7228)

This is a peer reviewed pre-print version of the following article: Weight and Leptin Changes Among

Risperidone-Treated Youths With Autism: 6-Month Prospective Data, which has been published in final form at:

http://www.appi.org

http://www.appi.org/SearchCenter/Pages/Journal.aspx?ItemId=AJP

http://ajp.psychiatryonline.org/article.aspx?articleid $=176873$

(C) 2004 American Psychiatric Publishing, Inc.

\title{
Weight and Leptin Changes Among Risperidone-Treated Youths With Autism: 6-Month Prospective Data
}

\author{
Andrés Martin, M.D., M.P.H., Lawrence Scahill, M.S.N., Ph.D., George M. \\ Anderson, Ph.D., Michael Aman, Ph.D., L. Eugene Arnold, M.D., James \\ McCracken, M.D., Christopher J. McDougle, M.D., Elaine Tierney, M.D., \\ Shirley Chuang, M.S., Benedetto Vitiello, M.D., The Research Units on \\ Pediatric Psychopharmacology Autism Network
}

\section{Abstract}

\begin{abstract}
Objective: The authors examined the developmental impact and temporal characteristics of risperidone-associated weight change.

Method: Weight change was measured for 63 children and adolescents with autism treated with risperidone for 6 months. Change in serum leptin levels after 2 months was examined as a predictor of final weight gain in mixed regression models that controlled for site, gender, age, and risperidone dose.

Results: Age- and gender-standardized weight increased after 6 months of treatment (gross: mean $=5.6 \mathrm{~kg}[\mathrm{SD}=3.9]$; standardized: mean $=0.6 \mathrm{z}[\mathrm{SD}=0.5])$ and was positively correlated with weight gained after 1 month. Change in leptin levels after 2 months of treatment (mean $=-0.3 \mathrm{ng} / \mathrm{ml}, \mathrm{SD}=6.2$ ) $(\mathrm{N}=48)$ did not predict final weight gain.

Conclusions: Chronic risperidone exposure in children with autism causes weight gain in excess of developmentally expected norms that follows a curvilinear trajectory and decelerates over time. Serum leptin change does not reliably predict risperidone-associated weight gain.
\end{abstract}

Weight gain is a common adverse effect of treatment with antipsychotic drugs, especially atypical antipsychotics. A meta-analysis of 26 cohorts of risperidone-treated adults documented a mean increase of $2.1 \mathrm{~kg}(95 \%$ confidence interval=1.69-2.51) after 10 weeks (1), but less is known about the impact of risperidone or other atypical antipsychotic treatment on children, particularly during long-term exposure. Based on small samples (2) or retrospective chart reviews confounded by multiple drug use $(3,4)$, mean risperidone weight gains observed in children have varied from 0.8 to $3.2 \mathrm{~kg} /$ month.

Atypical antipsychotic-associated weight gain in childhood may set the stage for serious health risks such as hypertension, cardiovascular illness, or diabetes, but children pose a particular challenge in distinguishing normative from medication-related weight gain. In addition, there may be age effects on atypical antipsychotic-associated weight gain. For example, a pharmacovigilance study described a greater likelihood of excessive weight gain with olanzapine among children and adolescents than among adults (risk ratios of 4.3 and 3.2, respectively) (5).

There are no clinical or laboratory variables currently available to identify subjects at higher risk of accelerated weight gain during atypical antipsychotic treatment. Leptin, a hormone secreted by differentiated adipocytes in direct proportion to body fat stores, is a marker of excessive weight gain. It exerts negative feedback on hypothalamic appetite regulation. Rapid increases in serum leptin levels have been associated with clozapine (6) or olanzapine (7) among 
adults, but there are no comparable data for pediatric populations. Moreover, early leptin level change has not been examined as a potential predictor of eventual weight gain.

This report describes prospectively collected data on weight and leptin levels among youths treated with risperidone for 6 months.

\section{Method}

Children with autism (ages 5 to 17) accompanied by aggression, agitation, or self-injurious behaviors were treated with risperidone or placebo as part of a previously described randomized controlled trial (8). Nonresponders to placebo were openly treated with risperidone. Positive responders in the acute phase were treated openly for an additional 4 months for a total of 6 months of risperidone treatment in all 63 subjects (9). The protocol was approved by the institutional review board at each site and the National Institute of Mental Health Data and Safety Monitoring Board, and written informed consent (and assent, when feasible) was obtained from a parent or guardian prior to enrollment. Of the 101 outpatients randomized, monthly measures of weight, height, and body mass index were available for those 63 completing the 6-month treatment course (mean age $=8.6$ years, $\mathrm{SD}=2.9$; racial breakdown was $70 \%$ white, $30 \%$ minority). Nonfasting serum leptin levels were available at baseline, 2 months, and end-point for 45 of these children. In addition to absolute measures, weight and body mass index were transformed to standardized $\mathrm{z}$ scores using anthropometric indices based on the 2000 Centers for Disease Control and Prevention age- and gender-normed growth charts (http://www.cdc.gov/growthcharts/). Unlike percentile scores, which group outliers ( $<5$ th or $>95$ th percentile), $\mathrm{z}$ scores permit the quantitative tracking of all individuals, regardless of their degree of obesity.

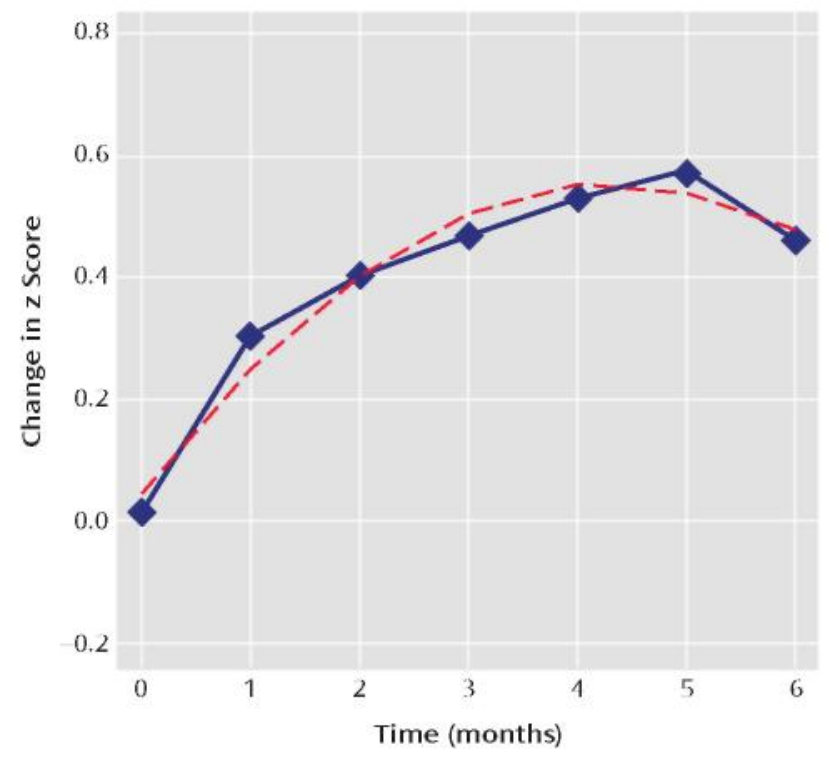

FIGURE 1. Standardized Weight Change Over 6 Months Among 63 Children and Adolescents With Autism Treated With Risperidone ${ }^{\mathrm{a}}$

${ }^{a}$ Weight was transformed to standardized z scores by using anthropometric indices based on the 2000 Centers for Disease Control and Prevention age- and gender-normed growth charts. The dotted line represents the best fit (upon including a quadratic term) for the observed data $\left(\mathrm{R}^{2}=0.96 ;-2 \log\right.$ likelihood change $=41.4, \mathrm{df}=1$, $\mathrm{p}<0.001)$.

Paired t tests were used to assess change between baseline and 6-month values in weight, 
body mass index, and leptin levels. Pearson coefficients were calculated for the correlation between weight gained at months 0 to 1 and 1 to 6 . A mixed regression model was fit using change in z score for weight as outcome, and change in leptin levels between baseline and 2 months as predictor. The independent variables of site, gender, age, weight $\mathrm{z}$ score, and mean risperidone dose were used as covariates.

\section{Results}

Absolute weight and body mass index increased by $16.7 \%$ (mean $=5.6 \mathrm{~kg}, \mathrm{SD}=3.9$ ) and $10.6 \%$ (mean $=2.0 \mathrm{~kg} / \mathrm{m}^{2}, \mathrm{SD}=1.9$ ), respectively, after 6 months of treatment with risperidone. There was wide individual variation in the changes in weight seen (range $=-4.0$ to $15.3 \mathrm{~kg}$ ). Weight gain was not explained on the basis of developmentally normative growth alone, as reflected by a steady change in standardized $\mathrm{z}$ scores for weight (Figure 1). Further, the rate of weight gain was not stable over time, and the introduction of a quadratic effect significantly improved the curve's fit, consistent with a polynomial (curvilinear), rather than a constant (linear), temporal course. Stated alternatively, the average weight gain of $0.88 \mathrm{~kg} / \mathrm{month}(5.8 \mathrm{~kg}$ over 6 months) was significantly lower than that of $1.4 \mathrm{~kg} /$ month seen during the first 2 months of treatment (mean $=2.8 \mathrm{~kg}, \mathrm{SD}=2.9$ ), suggesting a decreasing rate of excess weight gain with chronic treatment.

The mean change in serum leptin levels after 6 months of risperidone treatment was small (mean $=-0.6[\mathrm{SD}=7.4]$; mean baseline leptin concentration=6.5 $\mathrm{ng} / \mathrm{ml}[\mathrm{SD}=6.7]$ ), and the change in level between 0 and 2 months was similar in the risperidone- and placebo-treated groups $(t=0.7, d f=73, p=0.48)$. Moreover, among the 45 treated youths with levels available at 2 months, leptin change between baseline and 2 months (mean change $=-0.3 \mathrm{ng} / \mathrm{ml}, \mathrm{SD}=6.2$ ) did not significantly predict weight gain at 6 months $(\beta=0.03, \mathrm{SE}=0.03 ; \mathrm{t}=1.07, \mathrm{df}=446, \mathrm{p}=0.29)$. Regression analyses using change in $\mathrm{z}$ score over time as the outcome showed no significant effects for age (mean for the entire sample $=8.8$ years, $\mathrm{SD}=2.8$ ), dose (mean=1.8 $\mathrm{mg} / \mathrm{day}, \mathrm{SD}=$ $0.5)$, gender ( $78 \%$ male), site, or baseline weight $\mathrm{z}$ score (mean=0.4, $\mathrm{SD}=1.4$ ). Predictably, change in weight after 1 month was correlated with change in weight between months 1 and 6 , whether the change was expressed as kilograms (mean 1 -month change $=1.7 \mathrm{~kg}[\mathrm{SD}=1.4]$; $\mathrm{r}=0.50, \mathrm{p}<0.001$ ) or as $\mathrm{z}$ scores (mean 1-month change $=0.3 \mathrm{z}[\mathrm{SD}=0.2] ; \mathrm{r}=0.37, \mathrm{p}<0.01$ ).

\section{Discussion}

These data provide accurate estimates of weight gain associated with risperidone treatment in children and adolescents. In contrast to previous reports, these findings are based on prospectively collected data and are not confounded by concomitant medication use. Moreover, using standardized measures of weight and body mass index change distinguishes developmentally normative from medication-related weight gain. These prospectively derived estimates for absolute and standardized weight gain at 6 months (mean=5.6 $\mathrm{kg}$ [SD=3.9] and 0.5 $\mathrm{z}[\mathrm{SD}=0.6]$, respectively) are slightly lower than those seen in an earlier, retrospective study with the heretofore largest pediatric sample size (mean=7.0 $\mathrm{kg}[\mathrm{SD}=5.2]$ and $0.7 \mathrm{z}[\mathrm{SD}=1.3] ; \mathrm{N}=37$ ) (4). Our results also indicate that, in the group as a whole, there is a curvilinear chronology for drug-induced weight gain, with gradual slowing over time.

Accurate estimates of risperidone-associated weight gain are relevant to clinical risk-benefit analysis. Early identification of youths at high risk for extreme weight gain (for example, $>1 \mathrm{z}$ at 6 months) could allow minimizing drug exposure, considering alternative treatments, or initiating aggressive diet and exercise regimens. Notably, weight gain at 1 month 
emerged as a powerful predictor of later weight gain in this study. Clinicians may want to seriously consider discontinuing risperidone or switching to an alternative agent when faced with excessive early weight gain. By contrast, baseline characteristics, risperidone dose, and serum leptin level changes failed to predict extreme weight gain at 6 months, although nonfasting sample collection may have contributed to our null finding for leptin.

The pathophysiology of atypical antipsychotic-associated weight gain remains poorly understood and probably involves increased appetite rather than changed metabolism (10). The results reported here suggest that the high leptin levels reported in the literature in association with atypical antipsychotic exposure may be an effect rather than the cause of weight gain. A possible mechanism of atypical antipsychotic-induced weight gain may be desensitization of leptin receptors so that the feedback from the adipocytes is not "heard" by the satiety center. Preliminary studies suggest an association between genetic factors (such as 5-HT $2 \mathrm{C}$ receptor gene loci) and vulnerability to weight gain (11) and warrant further examination.

\section{Acknowledgments}

The Research Units on Pediatric Psychopharmacology Autism Network comprises the following institutions and individuals: Yale University, New Haven, Conn. (Drs. Scahill, Martin, Anderson, and Volkmar and Ms. Koenig); UCLA, Los Angeles (Drs. McCracken, Shah, and Cronin); Ohio State University, Columbus (Drs. Aman, Arnold, and Lindsay); Kennedy Krieger Institute, Baltimore (Drs. Tierney, Ghuman, and Gonzalez); Indiana University, Bloomington (Drs. McDougle, Posey, and Swiezy); Columbia University, New York (Mr. Davies and Ms. Chuang); and the National Institute of Mental Health, Bethesda, Md. (Dr. Vitiello and Ms. Ritz).

\section{References}

1. Allison DB, Mentore JL, Heo M, Chandler LP, Cappelleri JC, Infante MC, Weiden PJ: Antipsychotic-induced weight gain: a comprehensive research synthesis. Am J Psychiatry 1999; 156: 1686-1696

2. Ratzoni G, Gothelf D, Brand-Gothelf A, Reidman J, Kikinzon L, Gal G, Phillip M, Apter A, Weizman R: Weight gain associated with olanzapine and risperidone in adolescent patients: a comparative prospective study. $\mathrm{J}$ Am Acad Child Adolesc Psychiatry 2002; 41:337-343

3. Kelly DL, Conley RR, Love RC, Horn DS, Ushchak CM: Weight gain in adolescents treated with risperidone and conventional antipsychotics over six months. J Child Adolesc Psychopharmacol 1998; 8:151-159

4. Martin A, Landau J, Leebens P, Ulizio K, Cicchetti D, Scahill L, Leckman JF: Risperidone-associated weight gain in children and adolescents: a retrospective chart review. J Child Adolesc Psychopharmacol 2000; 10:259-268

5. Woods SW, Martin A, Spector SG, McGlashan TH: Effects of development on olanzapine-associated adverse events. J Am Acad Child Adolesc Psychiatry 2002; 41:1439-1446

6. Bromel T, Blum WF, Ziegler A, Schulz E, Bender M, Fleischhaker C, Remschmidt H, Krieg JC, Hebebrand J: Serum leptin levels increase rapidly after initiation of clozapine therapy. Mol Psychiatry 1998; 3:76-80

7. Eder U, Mangweth B, Ebenbichler C, Weiss E, Hofer A, Hummer M, Kemmler G, Lechleitner M, Fleischhacker WW: Association of olanzapine-induced weight gain with an increase in body fat. Am J Psychiatry 2001; 158:1719-1722

8. Research Units in Pediatric Psychopharmacology Autism Network: Risperidone in children with autism and serious behavioral problems. N Engl J Med 2002; 347:314-321

9. Scahill L, McCracken J, McDougle CJ, Aman M, Arnold LE, Tierney E, Cronin P, Davies M, Ghuman J, Gonzalez N, Koenig K, Lindsay R, Martin A, McGough J, Posey DJ, Swiezy N, Volkmar F, Ritz L, Vitiello B: Methodological issues in designing a multisite trial of risperidone in children and adolescents with autism. J Child Adolesc Psychopharmacol 2001; 11:377-388

10. Gothelf D, Falk B, Singer P, Kairi M, Phillip M, Zigel L, Poraz I, Frishman S, Constantini N, Zalsman G, Weizman A, Apter A: Weight gain associated with increased food intake and low habitual activity levels in male adolescent schizophrenic inpatients treated with olanzapine. Am J Psychiatry 2002; 159: 1055-1057

11. Reynolds GP, Zhang ZJ, Zhang XB: Association of antipsychotic drug-induced weight gain with a 5-HT2C receptor gene polymorphism. Lancet 2002; 359:2086-2087 